Politik Ekonomik Kuram 2019, Cilt 3(2), 273-288

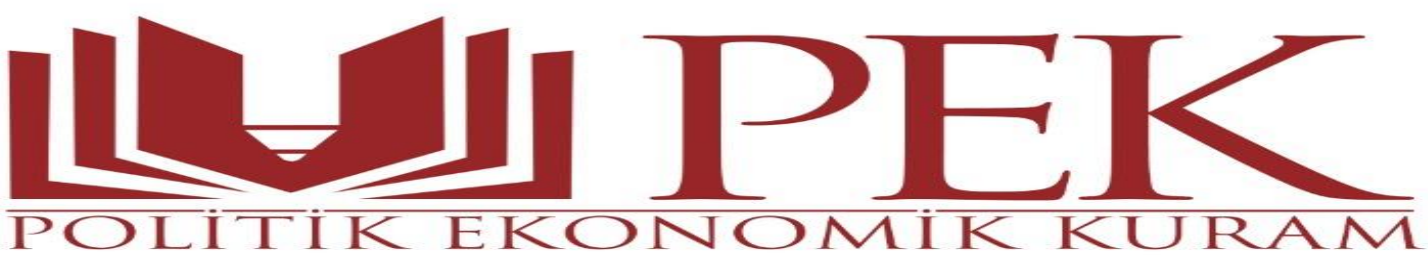

\title{
Partizan Modelin Çin ve Türkiye Ekonomilerine Etkisinin İncelenmesi: Ampirik Bir Analiz
}

\author{
Ali ŞEN ${ }^{1}$ Ceren PEHLIVAN ${ }^{2}$
}

Makale Bilgileri

Makale Geçmişi:

Makalenin Yüklendiği Tarih: 04.08.2019

Makalenin Kabul Edildiği Tarih: 2.11.2019

Anahtar Kelimeler: Partizan Model, Regresyon Analizi, Zaman Serisi

\footnotetext{
${ }^{1}$ Prof. Dr., İnönü Üniversitesi, İktisadi ve İdari Bilimler Fakültesi, İktisat Bölümü, ali.sen@inonu.edu.tr

2 Doktora Öğrencisi, İnönü Üniversitesi Sosyal Bilimler Enstitüsü , İktisat Bölümü, pehlivanceren23@hotmail.com
} 
Şen, A. ve C. Pehlivan (2019), "Partizan Modelin Çin ve Türkiye Ekonomilerine Etkisinin İncelenmesi: Ampirik Bir Analiz”, Politik Ekonomik Kuram, Cilt 3(2)

\section{Özet}

Partizan model, ekonomide yaşanan siyasal dalgalanmaların firsatçı politikalardan ziyade partizan eğilimlerden kaynaklandığını savunmaktadır. Hibbs' göre sol görüşlü partiler ekonomide işsizliğe öncelik verirken, sağ görüşlü partiler enflasyonu azaltmaya yönelik politikalara öncelik vermektedirler. 1990-2017 yılları için Türkiye ve Çin ekonomilerinin incelendiği çalışmada seçim dönemlerinde genel olarak Partizan modelin etkisinin olup olmadığının belirlenmesi amacıyla tek bir seçim kukla değişkeninin kullanıldığı zaman serisi analizi yapılmıştır. Çalışmada kullanılan kukla değişkenine ait bulgular, Partizan modele uygun olarak pozitif ve istatistiksel açıdan anlamlı sonuçlar vermiştir.

\section{Examining of the Effects of Partisan Model on the Economies of China and Turkey: An Empirical Analysis}

\section{Abstract}

The partisan model argues that political fluctuations exist in the economy originates from partisan tendencies rather than opportunistic policies. According to Hibbs, while left-wing parties give priority to unemployment in the economy, right-wing parties give priority to policies aiming to reducing inflation. We investigate that whether the effect of partisan models is exist in the economies of China and Turkey during general elections between 1990 and 2017. In doing so, a time series analysis that uses only one dummy variable is employed. The findings of the dummy variable used in this study showed positive and statistically significant results in accordance with the Partisan model.

Key words: PartisanModels, RegressionAnalysis, TimeSeries 
Şen ,A. ve C. Pehlivan, (2019), "Partizan Modelin Çin ve Türkiye Ekonomilerine Etkisinin İncelenmesi: Ampirik Bir Analiz”, Politik Ekonomik Kuram, Cilt 3(2)

\section{Giriş}

Demokratik sistemlerde seçimler, halkın tercihlerinin siyasete yansımasıdır. Politikacılar görev süreçleri boyunca seçim döneminde vaat ettikleri söylemleri gerçekleştirmeye çalışırlar. Kişiler seçim kararlarını verirken ideolojik olarak davrandıkları gibi pragmatik olarak da karar verebilmektedirler. Hükümetlerin sergiledikleri performans, siyasal ve ekonomik ilişkinin güçlenmesine yol açmaktadır. Ekonomik etkinlik, siyasilerin görevde kalma ve tekrar seçilme süreçlerini doğrudan etkileyen bir faktördür. Ekonomi ve siyasi ilişkinin varlığı 1970'li yıllarda "siyasal ekonomik yaklaşım" teorisiyle açıklanmaya çalışılmıştır. Politik Konjonktür Akımı, Pozitif Yaklaşım, Politik Konjonktür Analizi gibi birçok başlık altında bu iki değişken arasındaki ilişki incelenmeye çalışılmıştır.

1970'li yılların ortasında "Geleneksel Politik Konjonktür" modelleri başlığı altında iki temel görüş ortaya koyulmuştur. Bunlardan ilki Nordhaus'un savunduğu Fırsatçı Model'dir. Nordhaus (1975), siyasal otoritelerin aldıkları kararların arkasında ekonomik nedenlerin olduğunu savunmaktadır. Bireylerin karar alırken ortaya koyduğu akılcı davranış ilkesi siyasiler için de geçerlidir. Siyasi partiler seçimleri kazanmayı amaçlarken, seçmenler de faydalarını ve çıkarlarını maksimize etmeyi amaçlamaktadırlar (Özsoylu, 1992: 280). Seçmenler kendi çıkarlarına uygun bir siyasi partiyi seçerken ekonomiye ilişkin vaatleri dikkate almaktadırlar. Frey (1984), bu ilişkiyi politik-ekonomik model yardımıyla açıklamaya çalışmıştır. Model, hükümetlerin seçimleri kazanması veya mevcut durumlarını devam ettirmesini ekonomik istikrarın varlığına bağlamıştır. Politik sektörlerle ekonomik sektörler arasında iki yönlü bir ilişkinin olduğunu öne sürmüştür. İki değişken arasındaki bağ seçimler yoluyla sağlanmakta ve sürdürülmektedir (Frey, 1984: 305). Hükümetler seçim dönemi boyunca genişletici para ve maliye politikalarını devreye koyarlar. Popülist politikalarla kamu harcamalarını artırma yoluna giderler. Seçmen miyopluğu olarak tanımlanan bu sistemle kısa süreliğine seçmenlerin istekleri karşılanır. Seçimin bitmesiyle birlikte politikacılar verdikleri sözleri yerine getirmek için kısa bir süre daha harcamaları artırma yoluna giderler (William, 1975: 169-170). Ancak belli bir sürenin geçmesinden sonra ekonomide izlenen genişletici politikaların sonucu olarak ekonomide dalgalanmalar meydana gelmektedir.

Siyasal Ekonomik Yaklaşım, kamu harcamalarındaki artış sonucu oluşan ekonomik dalgalanmalarının sebebini iki başlık altında toplamıştır. Siyasi otorite ekonomiyi iyileştirecek yeteneğe sahip olmadığından kamusal harcamaları artırarak ekonomide canlılık sağlamaya çalışmaktadır. İkinci neden olarak ise; seçimi kazanmak isteyen partiler işsizlik düzeyini düşürmek, maaşlara zam yapmak gibi popülist eylemleri tercih etmektedirler (Özsoylu, 2016: 
Şen ,A. ve C. Pehlivan, (2019), "Partizan Modelin Çin ve Türkiye Ekonomilerine Etkisinin İncelenmesi: Ampirik Bir Analiz", Politik Ekonomik Kuram, Cilt 3(2)

281). Nordhaus, seçimlerden sonra hükümetlerin işsizliği artıran, enflasyonu düşürmeye çalışan politikalar izlediğini öne sürmektedir. Seçimler yaklaştıkça düşük işsizlik ve 1lımlı bir enflasyon oranı tercih edilirken seçim sonrası tam tersi politikaların devreye koyulduğunu belirtmektedir (Borooah, 1988: 72-73). İzlenen politikalar ekonomik yapının zayıflamasına yol açmaktadır. Finansmanın emisyonla sağlandığı ekonomilerde yüksek enflasyon kaçınılmaz bir son olarak karşımıza çıkmaktadır. Türkiye'nin özellikle 1990'lı yıllarda sergilediği siyasi istikrarsızlık yapısı sonucunda artan emisyon hacmi enflasyonun kronikleşmesine yol açmıştır. Seçim dönemlerinde izlenen bu politika mali açıkların artmasına da yol açmıştır. Mali açıkların enflasyon üzerindeki etkisi iktisat teorisinde Monetarist ve Fiyat Düzeyi Mali Teorisi yaklaşımlarıyla ele alınmıştır. Monetarist yaklaşım; mali açıklığın para arzında bir artışa yol açacağını ve bu durumun sonucunda da fiyatlar genel seviyesinde bir artış yaşanılacağını savunmaktadır. Ekonomide yaşanacak mali şoklar enflasyonu etkilemektedir. Monetaristler enflasyonun parasal bir olgu olduğunu ve para arzında meydana gelen artışların ekonomide fiyatlar genel seviyesini arttırdığını belirtmektedirler (Serban, 2002: 11-12). Fiyat Düzeyi Mali Teorisine göre ise; enflasyon para miktarından ziyade ekonomide gerçekleşen borç stokundan etkilenmektedir. Para politikasının yerine mali politikalara önem verilmesi gerekmektedir. Mali politikalardan bağımsız bir süreç izleyen merkez bankası politikaları enflasyonun artmasına neden olmaktadır. Kısaca mali teori para ve enflasyon ilişkisinin uzun dönemde birbirini etkileme gücünün zayıf olduğunu savunmaktadır (Uygur, 2001: 11).

Geleneksel Politik Konjonktür yaklaşımıyla ilgili ikinci görüş Douglas Hibbs (1977) tarafından ortaya koyulmuştur. Partizan Model olarak ifade edilen modelde iktidarların siyasi görüşlerinin ekonomik eğilimlerin temel belirleyicisi olduğu belirtilmektedir. Sol görüşlü partilerin işsizlik ve gelir dağılımı üzerinde durduklarını, sağ görüşlü partilerin ise enflasyon ve dış dengeyi temel alarak ekonomik politikaları belirlediklerini ifade etmiştir.

Hibbs bu durumu belirli bir sıraya koyarak tablolaştırmıştır:

Tablo 1: Sanayileşmiş Toplumlarda Siyasi Partilerin İktisadi Hedefleri

\begin{tabular}{|c|c|c|c|}
\hline $\begin{array}{c}\text { Ekonomik Amaçların } \\
\text { Stralanması }\end{array}$ & Sosyalist-İsçi & Merkez & Muhafazakar \\
\hline 1 & Tam İstihdam & Fiyat İstikrarı & Fiyat İstikrarı \\
\hline 2 & $\begin{array}{c}\text { Gelir Dağılımının } \\
\text { Dengelenmesi }\end{array}$ & Ekonomik Büyüme & Dış Ödemeler Dengesi \\
\hline 3 & Ekonomik Büyüme & Tam İstihdam & Ekonomik Büyüme \\
\hline
\end{tabular}


Şen ,A. ve C. Pehlivan, (2019), "Partizan Modelin Çin ve Türkiye Ekonomilerine Etkisinin İncelenmesi: Ampirik Bir Analiz”, Politik Ekonomik Kuram, Cilt 3(2)

\begin{tabular}{|c|c|c|c|}
\hline 4 & Fiyat İstikrarı & $\begin{array}{c}\text { Gelir Dağılımının } \\
\text { Dengelenmesi }\end{array}$ & Tam İstihdam \\
\hline 5 & Diş Ödemeler Dengesi & $\begin{array}{c}\text { Dış Ödemeler } \\
\text { Dengesi }\end{array}$ & $\begin{array}{c}\text { Gelir Dağılımının } \\
\text { Dengelenmesi }\end{array}$ \\
\hline
\end{tabular}

\section{Kaynak: Hibbs, 1977: 1471}

Tablo 1'de sanayileşmiş ülkelerde iktisadi hedeflerin belirlenmesinde ideolojik görüşler belirtilmiştir. Hibbs'e göre sol görüşlü partiler düşük gelirli kesime hitap ederken, yüksek gelir grubunu hedef kitle olarak seçen partilerin önceliği enflasyon hedeflemesi olmaktadır. Merkez partiler de sağ partilerin görüşünü savunmakla beraber ekonomik büyümenin de gerçekleşmesini amaçlamaktadırlar.

Hibbs modeli başta ABD olmak üzere birçok gelişmiş ve gelişmekte olan ülkeler açısından uygulanan temel politikalar çerçevesinde incelemiştir. ABD' de Demokrat Parti işsizlikle ilgili politikalara önem verirken, Cumhuriyet Partisi'nin temsilcileri enflasyonu düşürmeyi amaçlamaktadır. Ülkemizde de özellikle 2006 yılından sonra fiyat istikrarının sağlanması temel hedef olarak belirlenmiştir.

Bu çalışmada 1990-2017 yılları arasında Türkiye ve Çin hükümetlerinin izledikleri politikalar Hibbs tarafından savunulan Partizan model çerçevesinde karşılaştırma yapılarak incelenmiştir. Sosyalist ve muhafazakar politikalar benimseyen iki ülkenin oluşturdukları politikaların ekonomiye yansıması ekonometrik açıdan irdelenmiştir. Çalışma girişi takiben literatür taramasıyla devam etmiş, son bölümde ise enflasyon, işsizlik, bütçe açığı, Gini katsayısı ve reel GSYİH değişkenleriyle birlikte kukla değişken kullanılarak Partizan modelin geçerliliği iki ülke için ayrı ayrı incelenmiştir. 28 gözlem kullanılarak yapılan çalışmada değişkenlere ilk olarak birim kök testleri yapılmış, daha sonra ise; Otoregresif Hareketli Ortalama Modeli $\operatorname{ARMA}(p, q)$ ile katsayılar yorumlanmıştır.

\section{Literatür}

Hibbs (1977), ABD ve İngiltere için yaptığı çalışmada sol görüşlü partilerin sağ görüşlü partilere göre işsizliği azaltmada daha etkin politikalar izlediği sonucuna ulaşmıştır. Çalışmada Box-Jenkis modeli analizi kullanılmış ve sol görüşlü partilerin işsizliği azaltmada daha etkin bir rol oynadığı ekonometrik olarak da kanıtlanmıştır.

Frey ve Schneider 1978 yılında ABD 'de seçim dönemlerinde partilerin seçimi kazanmak ve ellerinde bulundurdukları iktidarı kaybetmemek için kamusal harcamaları arttırdıklarını saptamıştır. Seçim dönemi bittikten sonra ise genişletici politikalardan uzaklaşıldı̆̆ görülmüştür. 
Şen ,A. ve C. Pehlivan, (2019), "Partizan Modelin Çin ve Türkiye Ekonomilerine Etkisinin İncelenmesi: Ampirik Bir Analiz", Politik Ekonomik Kuram, Cilt 3(2)

Alesina (1987) çalışması, rasyonel beklentiler modelini araştırmıştır. Hükümetlerin seçim dönemlerinde ortaya koyduğu politikaların sadece seçim döneminde geçerli olduğunu ve etkilerinin kısa süreli olduğunu belirtmiştir. Seçmenlerin sahip olduğu sağ veya sol görüşlerin oy vermede daha etkin bir rol oynağını ve siyasal istikrarın sağlanmasının görüşler üzerinde belirleyici olduğunu savunmuştur.

Garand (1988) 50 ABD eyaleti için Partizan modelin etkilerini incelemiştir. Çalışmada 1945 1984 dönemi içinde Demokrat parti hükümetlerinin kamu sektörü büyüklüğüne pozitif bir etki sağladığını ancak bu etkinin yeterli bir düzeyde olmadığı sonucuna ulaşmıştır.

Alesina vd. (1991) 18 OECD ülkesini kapsayan bir çalışma yapmışlardır. Çalışmada işsizlik ve büyüme gibi reel değişkenler üzerinde firsatçı politikaların etkisinin olmadığı sonucuna ulaşmışlardır. Enflasyon oranı üzerinde politik dalgalanmaların etkisinin olduğunu ve politika sonuçlarını istikrara kavuşturmanın belli bir süreç içerisinde olabileceğini belirtmişlerdir.

Berger ve Voitek (1997) Almanya için yapmış oldukları çalışmalarında, Politik Konjonktür Akımının seçim dönemlerinde etkili olduğunu saptamışlardır. 1950-1989 yıllarını içeren çalışmada muhafazakar politikaların izlendiği ve fiyat istikrarının sağlanmasının temel amaç olarak görülmesine rağmen seçim dönemlerinde genişletici politikalar izlendiğini belirtmişlerdir.

Alesina, Tavares ve Perotti (1998) OECD ülkeleri için yaptığı çalışmada partilerin oy toplamak için yaptıkları eylemlerin her zaman başarılı olamadığını belirtmişlerdir. Kişiler oy verirken vaatlerden ziyade ideolojik olarak karar verebildiklerini ve her zaman sonuçların beklentilere uygun olmadı̆̆ını göstermişlerdir.

Telatar (2000), Türkiye'de 1986-1997 yılları arasında enflasyonun seçim zamanlaması için açıklayıcı bir değişken olup olmadığını incelemiş ve sağ görüşlü partilerin özellikle enflasyonu azaltıcı politikalar izlediğini belirtmiştir.

Ergün (2000), Türkiye üzerine yaptığı çalışmasında seçim dönemlerinde uygulanan genişletici politikalar sonucunda ekonomide yüksek oranlı enflasyonun gerçekleştiğini belirtmiştir. Özellikle 1990'lı y1llarda ortaya koyulan siyasal istikrarsızlık ve kısa süreli olarak kurulan koalisyon hükümetlerinin ekonomide etkin politikaların gerçekleşmesine engel olduğunu savunmuştur. Genişletici politikaların emisyonla karşılanması ekonomik dengeleri olumsuz bir şekilde etkilemiştir.

Cusack (2001), 1961-1994 yılları arasında 14 OECD ülkesi için yaptığı ekonometrik analiz de para ve maliye politikalarının oluşturulmasında partizan politikaların etkili olduğunu ve sol parti hükümetlerinin, sağ parti hükümetlerinden farklı ekonomik politikalar uyguladığını 
Şen ,A. ve C. Pehlivan, (2019), "Partizan Modelin Çin ve Türkiye Ekonomilerine Etkisinin İncelenmesi: Ampirik Bir Analiz", Politik Ekonomik Kuram, Cilt 3(2)

belirtmiştir. Sol görüşlü partilerin ekonomide tam istihdamı sağlamaya çalıştıklarını, sağ parti hükümetlerin ise daha muhafazakar davranarak bütçe açıklarını azaltmaya çalıştıklarını ortaya koymuştur.

Treisman ve Gimpelson 2001 yılında Rusya için politik konjonktür modelini incelemişlerdir. Ekonomide ücretlerin iyileştirilmesine, eğitim ve sağlık harcamalarının arttırılmasına öncelik verildiği görülmüştür. Siyasal partilerin gelir dağılımının eşitliğine, enflasyon gibi makroekonomik araçlardan daha fazla önem verdiği saptanmıştır.

Akçoraoğlu ve Yurdakul (2004), 1987-2003 yıllarında Türkiye'de iktisadi büyüme, enflasyon ve bütçe açıkları değişkenlerini kullanarak politik konjonktür dalgalanmaların etkisinin varlığını araştırmışlardır. Seçim dönemlerinde harcamaların arttığı ve büyümenin enflasyona tercih edildiği sonucuna ulaşmışlardır.

Sezgin (2005), 1950-2003 y1llarında Türkiye ekonomisi için "politik konjonktür teorisi" ve "ekonomik oy verme teorisini" incelemiştir. Çalışma sonucunda kişilerin oy verme sürecinde ortaya koyulan politikalardan etkilendiği saptanmıştır.

Bräuninger (2005), sol ve sağ görüşlü partilerin ortaya koyduğu politikaların benzerlik gösterdiğini savunmuştur. OECD ülkeleri için yaptığg çalışmada incelediği 19 ülkede sağ ve sol görüşlü partilerin, parti programları ve ekonomik politikaları arasında istikrarlı bir ilişkinin olduğunu ortaya koymuştur.

Akalın ve Erkişi (2007), Nordhaus'un geleneksel firsatçı modelini Türkiye açısından incelemişlerdir. Çalışmada 1950-2006 döneminde gerçekleşen seçimlerin ekonomi üzerindeki etkilerini ayrı ayrı araştırmışlardır. Enflasyon, işsizlik, para arzı ve büyüme gibi değişkenlerin kullanıldığı çalışmada bazı değişkenlerin incelenen dönem içerisinde fırsatçı politika etkilerini yansıtmadığı sonucuna ulaşmışlardır.

Özkan ve Tarı, 2010 yılında 1985-2007 dönemini kapsayan bir çalışma ortaya koymuşlardır. Çalışmada GSYİH, para arzı ve kamu harcamaları değişkenleri kullanılarak incelenen dönemde ekonomide politik amaçlı bir sapmanın olup olmadığını araştırmışlardır. Analizde otoregresif hareketli ortalamalar modeli kullanılmış ve 1987 seçimlerinde değişkenler arasındaki ilişkini güçlü olmasına karşın bu etkinin 2002 ve 2007 seçimlerinde azaldığı görülmüştür.

Dash ve Raja (2013) yatırım ya da transfer harcamalarında sağ ve sol partiler arasında bir farklılık olmadığını, seçim dönemlerinde harcamaların arttı̆̆ını göstermişlerdir. 27 yıllık (19802007) bir zaman aralığını içine alan ve Hindistan'daki 14 eyalet için yapılan çalışmada sol görüşlü siyasi partilerin cari harcama oranlarının daha fazla olduğunu ortaya koymuşlardır. 
Şen ,A. ve C. Pehlivan, (2019), "Partizan Modelin Çin ve Türkiye Ekonomilerine Etkisinin İncelenmesi: Ampirik Bir Analiz", Politik Ekonomik Kuram, Cilt 3(2)

Literatürde Partizan ve Nordhaus Modelleri farklı ülkeler için farklı değişkenler kullanılarak incelenmiştir. Ülkeler seçim dönemlerinde oluşturdukları politikaları bağlı oldukları siyasi görüş çerçevesinde ortaya koymuşlardır. Çalışmamızda Çin'e ait verilerle Türkiye karşılaştırma yapılarak incelenmiştir. Birçok gelişmiş ülke için yapılan çalışmalardan farklı olarak komünist bir rejime sahip Çin ekonomisinin siyasi yapı üzerindeki etkisi, farklı bir siyasi rejime sahip olan Türkiye ile birlikte ele alınmıştır.

\section{Yöntem ve Metodoloji}

Türkiye ve Çin ekonomilerinin incelendiği çalışmada, farklı ideolojik görüşlerin benimsendiği iki ülke için ekonomide kullanılan araçların Hibbs tarafından ortaya koyulan Partizan modelle uyumluluğu irdelenmiştir. Çalışmada reel GSYİH, işsizlik, Gini katsayısı, enflasyon ve bütçe açı̆̆ı değişkenleri kullanılmıştır. Reel GSYİH değişkenin logaritması alınarak, diğer değişkenler ise düzey değerleriyle analize dahil edilmiştir. İki ülkedeki iktidardaki siyasi partilerin ideolojisindeki faklılığı göstermek için “parti R (right), L (left)" kukla değişkenine çalışmada yer verilmiştir. Değişkenlerin durağanlığının belirlenmesi için ilk olarak birim kök testleri yapılmıştır. Serilerin durağanlıkları Genişletilmiş Dickey Fuller (ADF), ve Phillips Perron (PP) birim kök testi ile incelenmiştir. Otoregresyon analizinin yapılabilmesi için gerekli varsayımlardan normallik varsayımının sağlanıp sağlanmadığının sınanmasında Jarque Bera (JB) testi kullanılmıştır. Belirlenen modeller test edildikten sonra hata terimleri arasında otokorelasyon olup olmadığı ise Breusch Godfrey (LM) test ile kontrol edilmiştir. Hata terimlerinin sabit varyansa sahip olması otoregresyon analizi için gerekli şartlardan bir diğeridir (Özkan ve Tarı, 2011: 228). Hata terimlerinin sabit varyanslı olup olmadığının belirlenmesinde ise ARCH LM testi kullanılmıştır. Değişkenler durağan hale geldikten sonra regresyon analiziyle Partizan modelin geçerliliği sınanmıştır. Analizde Otoregresif Hareketli Ortalama Modeli (ARMA) ile siyasal partilerin seçim döneminde partizan bir politika izleyip izlemediğini açıklamak için oluşturdukları model kullanılmıştır. Çalışmaya ait denklem;

$Y_{t}=\alpha+\beta_{1} Y_{t-1}+\beta_{2}$ PMDummy $+U_{t}$

şeklinde tahmin edilmiştir.

Denklemde Y terimi analizde kullanılan bağımlı değişken olan makro değişkenleri ifade ederken $Y_{t-1}$ bağımlı değişkenin bir dönem önceki gecikmeli değerini göstermektedir. Dummy ise, kukla değişkeni göstermektedir. PMDUMMY seçim dönemleri için "1”, diğer dönemler için " 0 " olarak tanımlanmıştır. $U_{t}$ ise hata terimlerini ifade etmektedir. 
Şen ,A. ve C. Pehlivan, (2019), "Partizan Modelin Çin ve Türkiye Ekonomilerine Etkisinin İncelenmesi: Ampirik Bir Analiz", Politik Ekonomik Kuram, Cilt 3(2)

Tablo 2: Türkiye ve Çin için Kullanılan Kukla Değişkenine ait Veriler 
Şen ,A. ve C. Pehlivan, (2019), “Partizan Modelin Çin ve Türkiye Ekonomilerine Etkisinin İncelenmesi: Ampirik Bir Analiz”, Politik Ekonomik Kuram, Cilt 3(2)

\begin{tabular}{|c|c|c|c|c|c|}
\hline $\begin{array}{c}\text { 1990-2017 Yılları } \\
\text { Arasında } \\
\text { Kurulan } \\
\text { Hükümetler } \\
\text { (Türkiye) }\end{array}$ & $\begin{array}{c}\text { Görevde } \\
\text { Kaldığı } \\
\text { Yıllar }\end{array}$ & $\begin{array}{c}\text { Kukla } \\
\text { Değişken }\end{array}$ & $\begin{array}{l}\text { 1990-2017 Yılları } \\
\text { Arasında Kurulan } \\
\text { Hükümetler (Çin) }\end{array}$ & $\begin{array}{c}\text { Görevde } \\
\text { Kaldığı Yıllar }\end{array}$ & $\begin{array}{c}\text { Kukla } \\
\text { Değişken }\end{array}$ \\
\hline Akbulut Hükümeti & $\begin{array}{l}09.11 .1989- \\
23.06 .1991\end{array}$ & $\begin{array}{l}\text { 1990: } 0 \\
\text { 1991:1 }\end{array}$ & Yang Shangkun & $\begin{array}{l}08.04 .1988- \\
27.03 .1993\end{array}$ & $\begin{array}{l}1990: 0 \\
1991: 0 \\
1992: 0 \\
1993: 1\end{array}$ \\
\hline $\begin{array}{l}\text { I.Y1lmaz } \\
\text { Hükümeti }\end{array}$ & $\begin{array}{l}23.06 .1991- \\
20.11 .1991\end{array}$ & 1991:1 & Jiang Zemin & $\begin{array}{l}27.03 .1993- \\
15.03 .2003\end{array}$ & $\begin{array}{l}1994: 0 \\
1995: 0 \\
1996: 0 \\
1997: 0 \\
1998: 0 \\
1999: 0 \\
2000: 0 \\
2001: 0 \\
2002: 0 \\
2003: 1\end{array}$ \\
\hline $\begin{array}{l}\text { VII.Demirel } \\
\text { Hükümeti }\end{array}$ & $\begin{array}{l}21.11 .1991- \\
25.06 .1993\end{array}$ & $\begin{array}{l}1992: 0 \\
1993: 1\end{array}$ & Hu Jintao & $\begin{array}{l}15.03 .2003- \\
14.03 .2013\end{array}$ & $\begin{array}{l}2004: 0 \\
2005: 0 \\
2006: 0 \\
2007: 0 \\
2008: 0 \\
2009: 0 \\
2010: 0 \\
2011: 0 \\
2012: 0 \\
2013: 1\end{array}$ \\
\hline I. Çiller Hükümeti & $\begin{array}{l}25.06 .1993- \\
05.10 .1995\end{array}$ & $\begin{array}{l}1994: 0 \\
1995: 1\end{array}$ & $\begin{array}{l}\mathrm{Xi} \quad \text { Jinping } \quad \text { (Şi } \\
\text { Cinping) }\end{array}$ & $\begin{array}{l}\text { 14.03.2013- } \\
\text { Devam Ediyor }\end{array}$ & $\begin{array}{l}2014: 0 \\
2015: 0 \\
2016: 0 \\
2017: 0\end{array}$ \\
\hline II.Çiller Hükümeti & $\begin{array}{l}05.10 .1995- \\
30.10 .1995\end{array}$ & 1995:1 & & & \\
\hline $\begin{array}{l}\text { III.Çiller } \\
\text { Hükümeti }\end{array}$ & $\begin{array}{l}30.10 .1995- \\
06.03 .1996\end{array}$ & 1996:1 & & & \\
\hline $\begin{array}{l}\text { II.Yılmaz } \\
\text { Hükümeti }\end{array}$ & $\begin{array}{l}06.03 .1996- \\
28.06 .1996\end{array}$ & 1996:1 & & & \\
\hline
\end{tabular}


Şen ,A. ve C. Pehlivan, (2019), "Partizan Modelin Çin ve Türkiye Ekonomilerine Etkisinin İncelenmesi: Ampirik Bir Analiz”, Politik Ekonomik Kuram, Cilt 3(2)

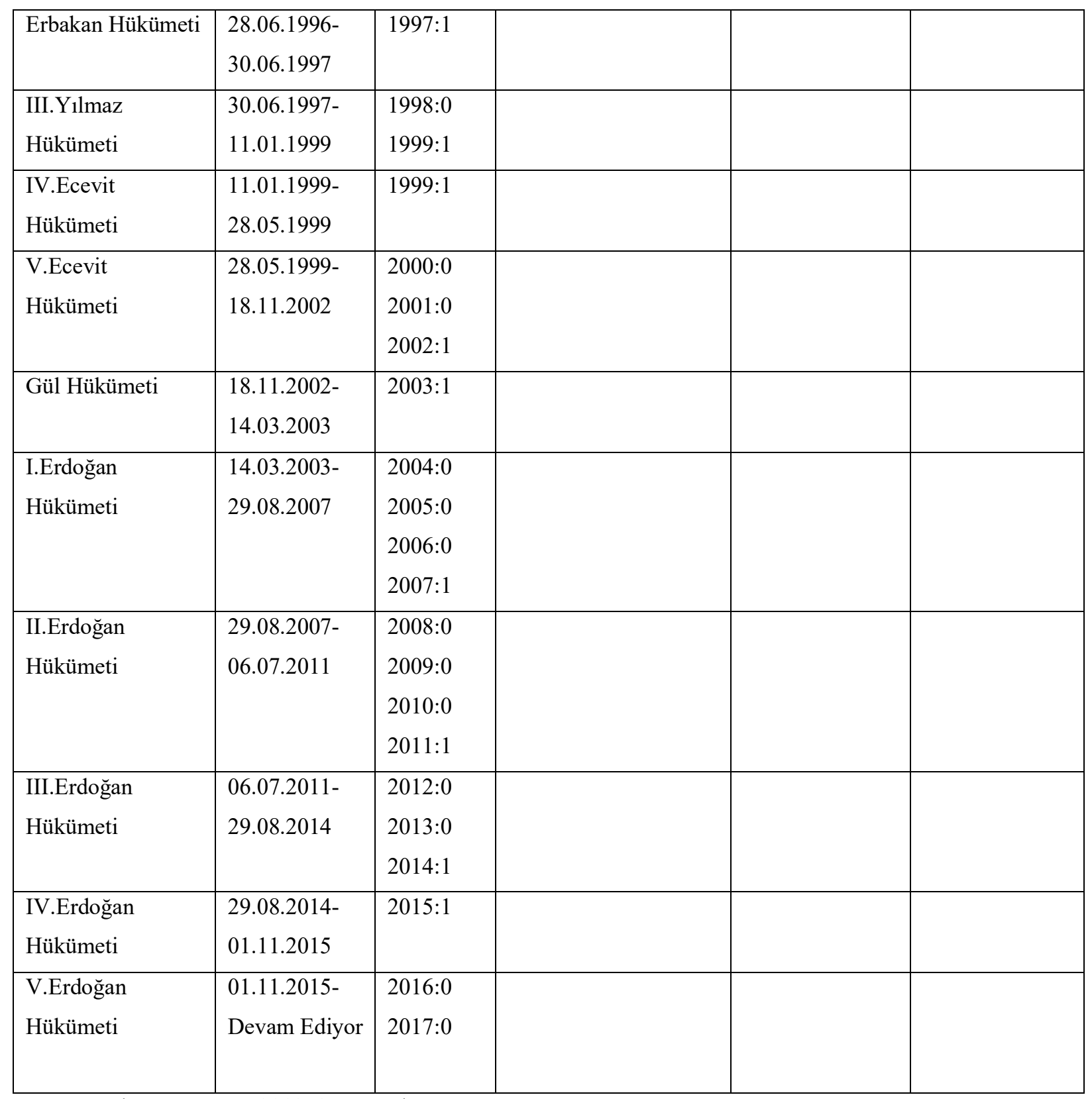

Kaynak: Akan ve Kanca: 2012: 8, www.tbmm.gov.tr

Tablo 2'de her iki ülkeye ait siyasi hükümetlerin görevde kalma süreleri verilmiştir. Çin hükümeti tek parti rejimiyle yönetilen ve on yılda bir hükümet başkanının seçildiği bir siyasi yapıya sahip olduğundan başkanın görev süresinin bittiği yıllar 1 olarak alınmıştır. Diğer yıllar için kukla değişkeni 0 olarak alınmıştır.

Tablo 3: Değişkenlerin Tanımlanması ve Kaynakları

\begin{tabular}{|c|c|c|}
\hline Değişkenler & Açıklaması & Kaynă̆ı \\
\hline LGDP & Reel GSYİH (Yıllık US \$ ) & Dünya Bankası \\
\hline INF & Enflasyon Oranı ( TÜFE \%) & Dünya Bankası \\
\hline UNEMP & İşsizlik (\%) & Dünya Bankası \\
\hline
\end{tabular}


Şen ,A. ve C. Pehlivan, (2019), "Partizan Modelin Çin ve Türkiye Ekonomilerine Etkisinin İncelenmesi: Ampirik Bir Analiz”, Politik Ekonomik Kuram, Cilt 3(2)

\begin{tabular}{|c|c|c|}
\hline GINI & Gini Katsayısı & $\begin{array}{l}\text { China Statistical Yearbook / National } \\
\text { Bureau of Statistics of China / Dünya } \\
\text { Bankası }\end{array}$ \\
\hline BDG & Bütçe Açı̆̆ı (Bütçe Açı̆̆ı/GSYİH) & $\begin{array}{c}\text { China Statistical Yearbook / National } \\
\text { Bureau of Statistics of China / Dünya } \\
\end{array}$ \\
& & Bankası \\
\hline
\end{tabular}

\subsection{Birim Kök Testleri}

ADF Testi, istatistikte zaman serisinin birim kök içerip içermediğini incelemeye yarayan testtir. Test farklı şekillerde yorumlanarak ve geliştirilerek kullanılmıştır. ADF testi hata terimlerinin sabit varyans içerdiklerini kabul eder. Değişkenlere gecikmeli değerler eklenmiş ve ADF birim kök testi otokorelasyon sorunundan arındırılmıştır. ADF birim kök testi regresyon denklemi;

$\Delta Y_{t}=(\rho-1) Y_{t-1}+U t=\delta Y_{t-1}+U t$

şeklinde gösterilir.

Denklemde $\Delta$, değişkeninin birinci fark değerini göstermektedir. Analiz sonucunda model tahmin edilir ve sonra $\delta=0$ kısıtı seriye uygulanır. Seride değişkenler rassal bir değişkene bağlı olduğundan Ho hipotezi birim kök vardır yani değişkenler durağan değildir şeklinde yorumlanır. ADF birim kök testinde artık değerler kullanıldığ 1 için standart $t$ istatistiği değeri yerine özel bir tabloya sahip olan $\tau$ istatistiği kullanılır (Enders, 2004: 229).

Dickey Fuller testi hata terimlerinin otokorelasyonsuz olduğunu savunmaktadır. Başka bir deyişle birbirinden bağımsız seyredip varyanslarının da sabit olduğunu ileri sürmektedir. Ancak pek çok zaman serisi bu varsayımlara ters düşmekte olup hem az hem de homojen olmayan bir yapı göstermektedir. Phillips ve Perron bunları göz önüne alarak PP testini geliştirmişlerdir. Bu amaçla gecikmeli fark değerlerini dikkate almadan parametrik olmayan istatistik test yöntemlerini kullanmışlardır (Gujarati ve Porter, 2012: 740).

Phillips ve Perron 1988 yılında yaptıkları çalışmalarla Dickey-Fuller'ın hata terimleri ile ilgili varsayımların kapsamını genişletmişlerdir. Regresyon denklemi şu şekildedir:

$\mathrm{Y}_{\mathrm{t}}=\mathrm{a}_{0}^{*}+\mathrm{a}_{1}^{*} \mathrm{y}_{\mathrm{t}-1}+\mu_{\mathrm{t}}$

$\mathrm{Y} \underset{\mathrm{t}=0}{\mathrm{a}} \dot{0}+\mathrm{a}_{1} \dot{\mathrm{y}}_{\mathrm{t}-1+{ }_{2}} \mathrm{a}^{\dot{0}}(\mathrm{t}-\mathrm{T} / 2)+\mu_{\mathrm{t}}$ 
Şen ,A. ve C. Pehlivan, (2019), "Partizan Modelin Çin ve Türkiye Ekonomilerine Etkisinin İncelenmesi: Ampirik Bir Analiz”, Politik Ekonomik Kuram, Cilt 3(2)

Burada T gözlem sayısını $\mu_{\mathrm{t}}$ hata terimlerinin dağılımını göstermektedir. Burada hata teriminin beklenen ortalaması sıfıra eşittir. Ancak burada hata terimleri arasında içsel bağlantının (serial correlation) olmadığı veya homojenlik varsayımı gerekli değildir. Bu açıdan bakıldığında Dickey-Fuller testinin bağımsızlık ve homojenite varsayımları Phillips-Perron testinde terk edilmiş hata terimlerinin zayıf bağımlılı̆̆ ve heterojen dağılımı kabul edilmiştir. Böylece Phillips-Perron, Dickey-Fuller t istatistiklerini geliştirmesinde hata terimlerinin varsayımları konusundaki sınırlamaları dikkate almamıştır (Walter, 2004: 239-240). Phillips-Perron testi, Dickey-Fuller testinden farklı olarak kritik değerleri Z ile göstermektedir. Bu testte trendsiz bir modelde $Z_{\alpha}$ kullanılmaktadır (Sevüktekin ve Nargeleçekenler, 2011: 365).

Phillips-Perron, $y_{t}=y_{t-1}+e_{t} \quad$ veri yaratan sürecinin olduğu temel hipotez altında $a_{0}{ }_{0}^{*} v e a_{1}{ }^{*}$ katsayıları ile ilgili hipotezleri test etmek için test istatistikleri türetmişlerdir. Phillips-Perron istatistiklerinin kritik değerleri Dickey-Fuller testi tarafından verilmektedir. Örnek vermek gerekirse yukarıda ki modelde,

$\mathrm{Z}\left(\operatorname{ta}_{1}{ }^{*}\right): \mathrm{a}_{1}^{*}=1$ hipotezinin testi için kullanılmıştır.

$\mathrm{Z}\left(\operatorname{ta}_{1}\right): \mathrm{a}_{1}=1$ hipotezinin testi için kullanılmıştır.

$\mathrm{Z}\left(\operatorname{ta}_{2}\right): \mathrm{a}_{2}=0$ hipotezinin testi için kullanılmıştır.

$\mathrm{Z}\left(\varphi_{3}\right): \mathrm{a}_{1}=1$ ve $\mathrm{a}_{2}=0$ hipotezlerinin testi için kullanılmıştır (Yavuz, 2014: 304-305).

Zaman serilerinin stokastik bir seri olarak ortalaması, varyansı, kovaryansı ve daha yüksek dereceden momentleri incelenen herhangi bir zaman süresince değişmiyorsa veya seri periyodik dalgalanmalardan arınmışsa bu seriye durağan seri denilmektedir. Bunun sonucunda oluşan durama ise durağanlık denilmektedir (Özmen, 1986: 4-5).

Tablo 4: Değişkenlere ait Tanımlayıcı İstatistikler (Türkiye için)

\begin{tabular}{|c|c|c|c|c|c|c|c|}
\hline Değişkenler & Ortalama & $\begin{array}{c}\text { Standart } \\
\text { Sapma }\end{array}$ & $\begin{array}{c}\text { Varyasyon } \\
\text { Katsayısı }\end{array}$ & Çarpıklık & Basıklık & Jarque- & Gözlem \\
\hline LGDP & 26.662 & 0.711 & 0.026 & -0.034 & 1.369 & 3.107 & 28 \\
\hline INF & 38.105 & 33.496 & 0.879 & 0.465 & 1.654 & 3.125 & 28 \\
\hline UNEMP & 11.556 & 3.153 & 0.272 & 1.334 & 3.718 & 8.914 & 28 \\
\hline GINI & 0.465 & 0.079 & 0.169 & 0.548 & 1.560 & 3.819 & 28 \\
\hline BDG & 37.064 & 5.479 & 0.174 & 0.571 & 2.705 & 1.623 & 28 \\
\hline
\end{tabular}


Şen ,A. ve C. Pehlivan, (2019), "Partizan Modelin Çin ve Türkiye Ekonomilerine Etkisinin İncelenmesi: Ampirik Bir Analiz”, Politik Ekonomik Kuram, Cilt 3(2)

Not:Çarpıklık değeri $<0$ ise; sola çarpık, Çarpıklık değeri $>0$ ise; sağa çarpıktır. Basıklık değeri $<3$ ise; basık, Basıklık değeri $>3$ ise; diktir.

Tablo 5: Değişkenlere ait Tanımlayıcı İstatistikler (Çin için)

\begin{tabular}{|c|c|c|c|c|c|c|c|}
\hline Değişkenler & Ortalama & $\begin{array}{c}\text { Standart } \\
\text { Sapma }\end{array}$ & $\begin{array}{c}\text { Varyasyon } \\
\text { Katsayısı }\end{array}$ & Çarpıklık & Basıklık & $\begin{array}{c}\text { Jarque- } \\
\text { Bera }\end{array}$ & \begin{tabular}{c} 
Gözlem \\
\hline LGDP
\end{tabular} \\
\hline INF & 4.185 & 5.721 & 1.367 & 2.123 & 7.281 & 42.437 & 28 \\
\hline UNEMP & 3.548 & 0.667 & 0.187 & -0.533 & 1.826 & 2.935 & 28 \\
\hline GINI & 0.445 & 0.039 & 0.087 & -0.779 & 2.518 & 3.106 & 28 \\
\hline BDG & 21.726 & 10.282 & 0.473 & -0.385 & 2.109 & 1.620 & 28 \\
\hline
\end{tabular}

Not: Çarpıklık değeri $<0$ ise; sola çarpık, Çarpıklık değeri $>0$ ise; sağa çarpıktır. Basıklık değeri $<3$ ise; basık, Basıklık değeri $>3$ ise; diktir.

Türkiye'ye ait standart sapma değeri en yüksek enflasyon değişkeninde ortaya çıkmıştır. Değişkenlere ait standart sapma değeri oynaklık göstergesi olarak da ifade edilmektedir. Değişkenler arasında asimetrik dağılımı simgeleyen çarpıklık değeri; Gini katsayısı, bütçe açığı, işsizlik ve enflasyon için sağa çarpıkken, reel GSYİH için sola çarpıktır. Ayrıca değişkenlerde kuyruk dağılımını gösteren basıklık değeri; reel GSYİH, enflasyon, Gini katsayısı ve bütçe açığı için basıkken, işsizlik için diktir. Varyasyon katsayısı standart sapmanın ortalamaya bölünmesiyle elde edilmekte ve katsayısı en yüksek olan değişken seride daha fazla etkiye neden olmaktadır. Enflasyon değişkeni analizde en yüksek değişkenliği göstermektedir. Çin'e ait veriler incelendiğinde; standart sapma değeri en yüksek bütçe açığı değişkeninde ortaya çıkmıştır. Çarpıklık değeri; işsizlik, Gini katsayısı ve bütçe açı̆̆ı için sola çarpıkken, reel GSYİH ve enflasyon için sağa çarpıktır. Basıklık değeri; reel GSYİH, işsizlik, Gini katsayısı ve bütçe açığı için basık, enflasyon için ise diktir. Varyasyon katsayısı olarak enflasyon değişkeni en büyük değere sahiptir. Bu değişkeni bütçe açığı izlemektedir.

\section{Tablo 6: Türkiye için Birim Kök Sonuçları}

\begin{tabular}{|c|c|c|c|c|c|c|c|c|c|c|}
\hline \multirow{7}{*}{ 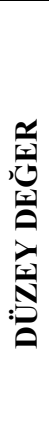 } & \multirow{2}{*}{ Değişkenler } & \multicolumn{2}{|c|}{ Sabit } & \multicolumn{2}{|c|}{ Sabit + Trend } & \multirow{7}{*}{ 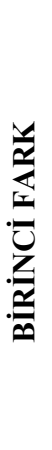 } & \multicolumn{2}{|c|}{ Sabit } & \multicolumn{2}{|c|}{ Sabit + Trend } \\
\hline & & $\begin{array}{c}\text { ADF } \\
\text { Değeri }\end{array}$ & Olasılık & $\begin{array}{c}\text { ADF } \\
\text { Değeri }\end{array}$ & Olasılık & & $\begin{array}{c}\text { ADF } \\
\text { Değeri }\end{array}$ & Olasılık & $\begin{array}{c}\text { ADF } \\
\text { Değeri }\end{array}$ & Olasılık \\
\hline & LGDP & -0.761 & 0.814 & -2.071 & 0.537 & & -5.633 & $0.000 * * *$ & -5.540 & $0.000 * * *$ \\
\hline & INF & -4.317 & 0.523 & -2.254 & 0.439 & & -1.482 & $0.002 * * *$ & -3.516 & $0.059 *$ \\
\hline & UNEMP & -3.129 & 0.136 & -2.179 & 0.480 & & -3.901 & $0.006^{* * *}$ & -4.553 & $0.007 * * *$ \\
\hline & $\overline{\text { GINI }}$ & -1.077 & 0.709 & -1.359 & 0.849 & & -5.997 & $0.000 * * *$ & -5.995 & $0.000 * * *$ \\
\hline & BDG & -2.661 & 0.193 & -2.518 & 0.317 & & -5.975 & $0.000 * * *$ & -6.008 & $0.000 * * *$ \\
\hline
\end{tabular}


Şen ,A. ve C. Pehlivan, (2019), "Partizan Modelin Çin ve Türkiye Ekonomilerine Etkisinin İncelenmesi: Ampirik Bir Analiz”, Politik Ekonomik Kuram, Cilt 3(2)

\begin{tabular}{|c|c|c|c|c|c|c|c|c|c|c|}
\hline \multicolumn{11}{|c|}{ Phillips-Perron (PP) } \\
\hline \multirow{7}{*}{ 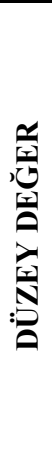 } & \multirow{2}{*}{ Değişkenler } & \multicolumn{2}{|c|}{ Sabit } & \multicolumn{2}{|c|}{ Sabit + Trend } & \multirow{7}{*}{ 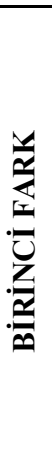 } & \multicolumn{2}{|c|}{ Sabit } & \multicolumn{2}{|c|}{ Sabit + Trend } \\
\hline & & $\begin{array}{c}\text { PP } \\
\text { Değeri }\end{array}$ & Olasilık & $\begin{array}{c}\text { PP } \\
\text { Değeri }\end{array}$ & Olasilık & & $\begin{array}{c}\text { PP } \\
\text { Değeri }\end{array}$ & Olasılık & $\begin{array}{c}\text { PP } \\
\text { Değeri }\end{array}$ & Olasılık \\
\hline & LGDP & -0.761 & 0.814 & -2.196 & 0.472 & & -5.632 & $0.000 * * *$ & -5.540 & $0.000 * * *$ \\
\hline & $\mathrm{INF}$ & -0.772 & 0.811 & -1.891 & 0.631 & & -5.048 & $0.000 * * *$ & -4.926 & $0.002 * * *$ \\
\hline & UNEMP & -3.441 & 0.118 & -1.875 & 0.639 & & -3.875 & $0.006 * * *$ & -4.513 & $0.007 * * *$ \\
\hline & GINI & -1.056 & 0.717 & -1.354 & 0.851 & & -5.947 & $0.000 * * *$ & -5.992 & $0.000 * * *$ \\
\hline & $\overline{\mathrm{BDG}}$ & -2.661 & 0.193 & -2.518 & 0.317 & & -6.052 & $0.000 * * *$ & -6.122 & $0.000 * * *$ \\
\hline
\end{tabular}

Tablo 7: Çin için Birim Kök Sonuçları

\begin{tabular}{|c|c|c|c|c|c|c|c|c|c|c|}
\hline \multirow{7}{*}{ 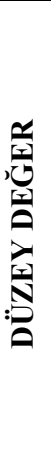 } & \multirow{2}{*}{ Değişkenler } & \multicolumn{2}{|c|}{ Sabit } & \multicolumn{2}{|c|}{ Sabit + Trend } & \multirow{7}{*}{ 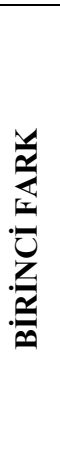 } & \multicolumn{2}{|c|}{ Sabit } & \multicolumn{2}{|c|}{ Sabit + Trend } \\
\hline & & $\begin{array}{c}\text { ADF } \\
\text { Değeri }\end{array}$ & Olas1lik & $\begin{array}{c}\text { ADF } \\
\text { Değeri }\end{array}$ & Olasilık & & $\begin{array}{c}\text { ADF } \\
\text { Değeri }\end{array}$ & Olasilık & $\begin{array}{c}\text { ADF } \\
\text { Değeri }\end{array}$ & Olasilık \\
\hline & LGDP & -0.919 & 0.765 & -2.226 & 0.455 & & -2.848 & $0.065^{*}$ & -2.832 & $0.009 * * *$ \\
\hline & INF & -2.773 & 0.177 & -2.919 & 0.174 & & -3.273 & $0.027 * *$ & -3.174 & $0.001 * * *$ \\
\hline & UNEMP & -2.403 & 0.150 & -0.558 & 0.973 & & -2.691 & $0.089^{*}$ & -3.581 & $0.051^{*}$ \\
\hline & $\overline{\text { GINI }}$ & -1.178 & 0.665 & -1.572 & 0.777 & & -3.302 & $0.025 * *$ & -3.493 & $0.061 *$ \\
\hline & BDG & -0.651 & 0.842 & -2.719 & 0.237 & & -3.394 & $0.020 * *$ & -3.227 & $0.000 * * *$ \\
\hline \multicolumn{11}{|c|}{ Phillips-Perron (PP) } \\
\hline \multirow{7}{*}{ 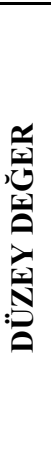 } & & & & Sabit & Trend & \multirow{7}{*}{ 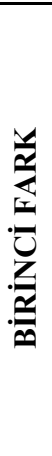 } & \multicolumn{2}{|c|}{ Sabit } & \multicolumn{2}{|c|}{ Sabit + Trend } \\
\hline & Değişkenler & $\begin{array}{c}\text { PP } \\
\text { Değeri }\end{array}$ & Olasılık & $\begin{array}{c}\text { PP } \\
\text { Değeri }\end{array}$ & Olasilık & & $\begin{array}{c}\text { PP } \\
\text { Değeri }\end{array}$ & Olasilık & $\begin{array}{c}\text { PP } \\
\text { Değeri }\end{array}$ & Olasılık \\
\hline & LGDP & -0.408 & 0.894 & -1.795 & 0.678 & & -2.849 & $0.065^{*}$ & -2.806 & $0.002 * * *$ \\
\hline & INF & -1.883 & 0.334 & -2.216 & 0.462 & & -3.391 & $0.020 * *$ & -3.302 & $0.088^{*}$ \\
\hline & $\overline{\text { UNEMP }}$ & -1.602 & 0.467 & 0.425 & 0.998 & & -2.691 & $0.089^{*}$ & -3.570 & $0.052 *$ \\
\hline & GINI & -2.708 & 0.856 & -1.795 & 0.678 & & -3.237 & $0.029 * *$ & -3.453 & $0.066^{*}$ \\
\hline & BDG & -0.940 & 0.759 & -2.643 & 0.265 & & -3.336 & $0.023 * *$ & -3.132 & $0.000 * * *$ \\
\hline
\end{tabular}

Not: $* * *, * *, *$ sırasıyla katsayıların $\% 1, \% 5$ ve $\% 10$ düzeyinde anlamlı olduğunu gösterir.

Seriye ait sonuçlar incelendiğinde analizde kullanılan değişkenler düzey değerinde yani I(0)' da durağan değildir. ADF ve PP testleri ile analiz edilen serilerin durağan hale getirilmesi için tüm değişkenlerin birinci farkı alınmıştır. Birim kök testleri tekrar uygulanmış ve değişkenler durağan hale getirilmiştir. Durağan hale gelen değişkenler için seride birim kökün olmadığını varsayan $\mathrm{H}_{0}$ hipotezi reddedilmiştir.

\subsection{Box-Jenkins Tahmin Modelleri}


Şen ,A. ve C. Pehlivan, (2019), "Partizan Modelin Çin ve Türkiye Ekonomilerine Etkisinin İncelenmesi: Ampirik Bir Analiz”, Politik Ekonomik Kuram, Cilt 3(2)

Box-Jenkins metodu tek değişkenli bir model olarak, geleceği tahmin etme metotlarından biri olarak kullanılmaktadır. Bu modelin en önemli varsayımı kısa dönem tahmininde oldukça başarılı olan bu metodun uygulandığı serinin, eşit zaman aralıklarıyla elde edilen gözlem değerlerinden oluşan kesikli ve durağan bir seri olmasıdır. Ayrıca bu şekilde kullanılan serilerde durağanlık kavramı da Box-Jenkins metodunun önemli varsayımlarındandır. Box-Jenkins metodunun kullanıldığı modeller; zamana bağlı tesadüfi karakterde olaylar ve bu olaylarla ilgili zaman serilerinin ise stokastik süreç olduğu varsayımına göre şekillendirilmiştir. Ayrıca iç bağımlılık en etkili biçimde dikkate alınmakta ve bu özelliklerinden dolayı Box-Jenkins modellerine doğrusal durağan stokastik modeller de denmektedir. Box-Jenkins modelleri üç ayrı başlık altında gruplandırılmaktadır. Bunlar; doğrusal durağan stokostik modeller, durağan olmayan doğrusal stokastik modeller ve mevsimlik modellerdir (Bircan ve Karagöz, 2003: 50). Seride kullanılan değişkenler aynı düzey değerde durağan halde olduklarından doğrusal durağan stokostik modellerden Otoregresif Hareketli Ortalama Modeli [ARMA (p, q)] kullanılmıştır.

\subsubsection{Otoregresif Hareketli Ortalama Modeli [ARMA (p, q)]}

Değişkenler üzerinde esneklik sağlamak için en az sayıda parametre kullanma ilkesini gerçekleștirmek amacıyla zaman serisi modellerinde bazı hallerde modele hem otoregresif hem de hareketli ortalama parametrelerinin alınması birçok faydalar sağlamaktadır. Ortaya koyulan pozitif sonuçlar ARMA (p, q) modelini ortaya çıkarmıştır (Kayım, 1985: 72). Bu modelin, bir zaman serisinin herhangi bir $\mathrm{t}$ dönemine ait $\mathrm{xt}$ gözlem değeri, bir önceki belirli sayıda $\mathrm{x}_{\mathrm{t}-1}, \mathrm{x}_{\mathrm{t}-}$ $2, \ldots \mathrm{x}_{\mathrm{t}-\mathrm{p}}$ gözlem değerlerinin ve $\mathrm{a}_{\mathrm{t}}, \mathrm{a}_{\mathrm{t}-1}, \mathrm{a}_{\mathrm{t}-2}, \ldots \mathrm{a}_{\mathrm{t}-\mathrm{q}}$ hata terimlerinin doğrusal birleşiminden meydana gelmektedir. ARMA (p, q) modeli;

$\mathrm{x}_{\mathrm{t}}=\varphi_{1} \mathrm{x}_{\mathrm{t}-1}+\varphi_{2} \mathrm{x}_{\mathrm{t}-2}+\ldots+\varphi_{\mathrm{p}} \mathrm{x}_{\mathrm{t}-\mathrm{p}}+\mathrm{a}_{\mathrm{t}}-\theta_{1} \mathrm{a}_{\mathrm{t}-1}-\theta_{2} \mathrm{a}_{\mathrm{t}-2-} \ldots-\theta_{\mathrm{q}} \mathrm{a}_{\mathrm{t}-\mathrm{q}}$
$\mathrm{x}_{\mathrm{t}}-\left(\varphi_{1} \mathrm{x}_{\mathrm{t}-1}+\varphi_{2} \mathrm{x}_{\mathrm{t}-2}+\ldots+\varphi_{\mathrm{p}} \mathrm{x}_{\mathrm{t}-\mathrm{p}}\right)=\mathrm{a}_{\mathrm{t}}-\theta_{1} \mathrm{a}_{\mathrm{t}-1}-\theta_{2} \mathrm{a}_{\mathrm{t}-2}-\ldots-\theta_{\mathrm{q}} \mathrm{a}_{\mathrm{t}-\mathrm{q}}$

şeklinde ifade edilmektedir (Bircan ve Karagöz, 2003: 51).

Seride kullanılan değişkenler için tek bir seçim kukla değişkeninin kullanıldığı ARMA modeli analiz sonucunda tahmin edilen otoregresif hareketli ortalamalar modelleri iki ülke için ayrı olarak Tablo 8 ve Tablo 9'da verilmektedir. 
Şen ,A. ve C. Pehlivan, (2019), "Partizan Modelin Çin ve Türkiye Ekonomilerine Etkisinin İncelenmesi: Ampirik Bir Analiz”, Politik Ekonomik Kuram, Cilt 3(2)

Tablo 8: Türkiye için Otoregresif Analiz Sonuçları

\begin{tabular}{|c|c|c|c|c|c|c|c|c|c|c|}
\hline \multirow{2}{*}{$\begin{array}{l}\text { Dönem } \\
(1990-2017)\end{array}$} & \multicolumn{2}{|c|}{ LGDP } & \multicolumn{2}{|c|}{ INF } & \multicolumn{2}{|c|}{ UNEMP } & \multicolumn{2}{|c|}{ GINI } & \multicolumn{2}{|c|}{ BDG } \\
\hline & Katsayı & Olasılık & Katsayı & Olasılık & Katsayı & Olasılık & Katsayı & Olasılık & Katsayı & Olasılık \\
\hline $\mathrm{C}$ & 26.646 & 0.000 & 35.323 & 0.029 & 12.672 & 0.000 & 0.474 & 0.000 & 37.408 & 0.000 \\
\hline PMDUMMY & 2850.478 & $0.088 *$ & 1547.87 & $0.095 *$ & 2478.14 & 0.214 & 78.458 & 0.128 & 1028.44 & $0.048 * *$ \\
\hline $\operatorname{AR}(1)$ & 1.705 & 0.000 & 1.979 & 0.000 & 0.278 & 0.459 & 0.237 & 0.291 & 1.238 & 0.006 \\
\hline $\operatorname{AR}(2)$ & -1.006 & 0.294 & -1.964 & 0.002 & 1.206 & 0.008 & 1.422 & 0.000 & -0.453 & 0.436 \\
\hline $\operatorname{AR}(3)$ & 0.814 & 0.458 & 1.804 & 0.001 & 0.305 & 0.590 & 0.228 & 0.365 & -0.055 & 0.944 \\
\hline $\operatorname{AR}(4)$ & -0.549 & 0.302 & -0.890 & 0.000 & -0.855 & 0.088 & -0.959 & 0.000 & 0.058 & 0.894 \\
\hline MA(1) & -1.382 & 0.955 & -1.412 & 0.977 & 1.146 & 0.999 & 0.646 & 0.993 & -0.670 & 0.999 \\
\hline MA(2) & 0.764 & 0.784 & 1.133 & 0.946 & -0.200 & 0.999 & -0.917 & 0.994 & -0.006 & 0.999 \\
\hline MA(3) & -1.376 & 0.931 & -1.111 & 0.982 & -1.323 & 0.999 & -0.873 & 0.986 & 0.664 & 0.999 \\
\hline $\mathrm{MA}(4)$ & 0.994 & 0.888 & 0.091 & 0.983 & -0.623 & 0.999 & 0.146 & 0.988 & -0.988 & 1.000 \\
\hline$R^{2}$ & \multicolumn{2}{|c|}{0.973} & \multicolumn{2}{|c|}{0.946} & \multicolumn{2}{|c|}{0.905} & \multicolumn{2}{|c|}{0.956} & \multicolumn{2}{|c|}{0.693} \\
\hline LM & \multicolumn{2}{|c|}{0.91} & \multicolumn{2}{|c|}{0.850} & \multicolumn{2}{|c|}{0.911} & \multicolumn{2}{|c|}{0.333} & \multicolumn{2}{|c|}{0.916} \\
\hline JB & \multicolumn{2}{|c|}{0.139} & \multicolumn{2}{|c|}{0.000} & \multicolumn{2}{|c|}{0.931} & \multicolumn{2}{|c|}{0.459} & \multicolumn{2}{|c|}{0.458} \\
\hline $\mathrm{ARCH}$ & \multicolumn{2}{|c|}{0.851} & \multicolumn{2}{|c|}{0.866} & \multicolumn{2}{|c|}{0.920} & \multicolumn{2}{|c|}{0.381} & \multicolumn{2}{|c|}{0.926} \\
\hline
\end{tabular}

Not: ${ }^{* *}$ ve $*$ sırasıyla katsayıların $\% 5$ ile \%10 düzeyinde anlamlı olduğunu gösterir.

LM, JB ve ARCH testi sonuçlarına göre regresyonlarda normallik varsayımının sağlandığı, otokorelasyon ve değiş̧en varyans probleminin olmadığı görülmektedir. Dolayısıyla regresyon analizi güvenilir sonuçlar vermektedir. Elde edilen sonuçlar Hibbs tarafından savunulan Partizan modelle bağdaşmaktadır. Türkiye'de incelene dönem içerisinde başa gelen hükümetlerin önceliği 2002'ye kadar yüksek büyüme iken, 2002'den sonra fiyat istikrarı ve bütçede denkliğin sağlanması olmuştur. Özellikle popülist eğilimlerin azalması enflasyonda istikrarın sağlanmasına neden olmuştur. Kukla değişkenine ait veriler Partizan modele uygun olarak pozitif ve istatistiksel açıdan anlamlı sonuçlar vermiştir.

Tablo 9: Çin için Otoregresif Analiz Sonuçları

\begin{tabular}{|l|l|l|l|l|l|l|l|l|l|l|}
\hline \multirow{2}{*}{$\begin{array}{l}\text { Dönem } \\
(\mathbf{1 9 9 0 - 2 0 1 7 )}\end{array}$} & \multicolumn{2}{|c|}{ LGDP } & \multicolumn{2}{c|}{ INF } & \multicolumn{2}{c|}{ UNEMP } & \multicolumn{2}{c|}{ GINI } & \multicolumn{2}{c|}{ BDG } \\
\cline { 2 - 12 }$y$ & Katsayı & Olasılık & Katsayı & Olasılık & Katsayı & Olasılık & Katsayı & Olasılık & Katsayı & Olasılık \\
\hline C & 28.427 & 0.000 & 3.654 & 0.145 & 3.434 & 0.000 & 0.426 & 0.000 & 21.469 & 0.038 \\
\hline PMDUMMY & $\mathbf{2 4 8 7 . 1 4}$ & $\mathbf{0 . 0 9 8 *}$ & $\mathbf{1 2 8 5 . 4 5}$ & $\mathbf{0 . 1 2 5}$ & $\mathbf{3 4 7 8 . 7 8}$ & $\mathbf{0 . 0 5 8 * *}$ & $\mathbf{9 8 7 . 4 5}$ & $\mathbf{0 . 1 7 8}$ & $\mathbf{8 4 7 . 4 6}$ & $\mathbf{0 . 2 5 4}$ \\
\hline AR(1) & 1.815 & 0.000 & 1.115 & 0.162 & 0.887 & 0.649 & 1.302 & 0.029 & 2.416 & 0.291 \\
\hline AR(2) & 0.150 & 0.000 & -0.945 & 0.410 & 0.205 & 0.932 & -0.282 & 0.803 & -1.921 & 0.740 \\
\hline
\end{tabular}


Şen ,A. ve C. Pehlivan, (2019), "Partizan Modelin Çin ve Türkiye Ekonomilerine Etkisinin İncelenmesi: Ampirik Bir Analiz”, Politik Ekonomik Kuram, Cilt 3(2)

\begin{tabular}{|c|c|c|c|c|c|c|c|c|c|c|}
\hline$\overline{A R(3)}$ & -1.766 & 0.000 & 1.224 & 0.152 & 0.605 & 0.688 & 0.468 & 0.680 & 0.261 & 0.961 \\
\hline $\operatorname{AR}(4)$ & 0.797 & 0.000 & -0.715 & 0.027 & -0.789 & 0.542 & -0.518 & 0.264 & 0.218 & 0.905 \\
\hline $\mathrm{MA}(1)$ & -0.363 & 0.966 & -0.082 & 0.999 & 0.500 & 0.999 & 0.067 & 1.000 & $\begin{array}{l}-1.224 \\
\end{array}$ & 0.963 \\
\hline MA(2) & -1.632 & 0.690 & 0.284 & 1.000 & -0.133 & 0.999 & 0.198 & 1.000 & -0.032 & 0.998 \\
\hline MA(3) & 0.363 & 0.937 & -0.698 & 1.000 & -1.047 & 0.999 & -0.609 & 1.000 & 0.898 & 0.968 \\
\hline $\mathrm{MA}(4)$ & 0.632 & 0.963 & -0.503 & 1.000 & -0.318 & 0.999 & -0.656 & 1.000 & -0.263 & 0.973 \\
\hline$\overline{R^{2}}$ & \multicolumn{2}{|c|}{0.998} & \multicolumn{2}{|c|}{$\frac{1}{0.763}$} & \multicolumn{2}{|c|}{$\frac{1}{0.957}$} & \multicolumn{2}{|c|}{$\frac{1}{0.949}$} & \multicolumn{2}{|c|}{$\frac{1}{0.941}$} \\
\hline LM & \multicolumn{2}{|c|}{0.985} & \multicolumn{2}{|c|}{0.879} & \multicolumn{2}{|c|}{0.459} & \multicolumn{2}{|c|}{0.620} & \multicolumn{2}{|c|}{0.717} \\
\hline JB & \multicolumn{2}{|c|}{0.341} & \multicolumn{2}{|c|}{0.128} & \multicolumn{2}{|c|}{0.156} & \multicolumn{2}{|c|}{0.713} & \multicolumn{2}{|c|}{0.514} \\
\hline ARCH & \multicolumn{2}{|c|}{0.987} & \multicolumn{2}{|c|}{0.258} & \multicolumn{2}{|c|}{0.505} & \multicolumn{2}{|c|}{0.644} & \multicolumn{2}{|c|}{0.738} \\
\hline
\end{tabular}

Not:** ve * sırasıyla katsayıların \% 5 ile \%10 düzeyinde anlamlı olduğunu gösterir.

Çin'e ait LM, JB ve ARCH testi sonuçlarına göre de regresyonlarda normallik varsayımının sağlandığı, otokorelasyon ve değişen varyans probleminin olmadığı görülmektedir. Sosyalist ideolojinin en önemli temsilcisi olan Çin'de izlenen politikaların başında yüksek büyüme oranlarının gerçekleştirilmesi bulunmaktadır. Yüksek iş gücü potansiyeline sahip olan ülkede ucuz iş gücünün bulunması ve reel ücretlerin düşüklüğü iş verenler açısından iş gücü talebini arttırmaktadır. Üretim fazlalığı fiyatların düşük tutulmasını sağlamaktadır. Dış ticarette önemli bir ticaret ortağı olan Çin, ürettiği ürünleri Dünya'nın birçok ülkesine ulaştırmaktadır. Regresyon analizi sonuçları Partizan modeli destekler niteliktedir. Kukla değişkenine ait verilere göre büyüme ve istihdam ülkenin öncelikli politikalarını oluşturmaktadır.

\section{Sonuç}

Çalışmada Partizan model farklı siyasal görüşe sahip iki ülke açısından ayrı ayrı olarak incelenmiştir. Literatürde birçok çalışma gelişmekte olan ülke grupları arasında yapılmıştır. Bu çalışmada ise analiz öznelleştirilerek iki ülkenin modele ilişkin özellikleri ayrıntılı olarak araştırılmıştır. Değişkenlerin durağanlığını belirlemek için öncelikle birim kök testleri uygulanmış, daha sonra değişkenlere ait verilerin farkı alınarak durağan hale getirilmiştir. Modele ilişkin tahminlerin yapılmasında değişkenlerin oto korelasyon, değişen varyans ve normal dağ̊lım sergileme süreci incelenmiştir. Çıkan sonuçlar doğrultusunda model belirlenmiş ve katsayılar yorumlanmıştır. Analiz sonucunda elde edilen bulguların incelenen teoriyle bağdaştığı sonucuna ulaşılmıştır. 
Şen ,A. ve C. Pehlivan, (2019), "Partizan Modelin Çin ve Türkiye Ekonomilerine Etkisinin İncelenmesi: Ampirik Bir Analiz", Politik Ekonomik Kuram, Cilt 3(2)

Ülkeler makroekonomi politikalarını politik çıkarlar doğrultusunda yönlendirmekte ve kullanmaktadırlar. Ülkelerin sahip olduğu ideolojik yapılar ortaya koydukları politikaları belirlemektedir. Türkiye ve Çin gibi iki farklı görüşü temsil eden ülkelerin incelendiği çalışmada Hibbs (1977) tarafından ortaya koyulan Partizan modelin geçerliliği sınanmaya çalışılmışıır. Ekonometrik analizlerle desteklenmeye çalışılan Partizan model incelenen dönemlerde ve incelenen iki ülke için istatistiksel açıdan anlamlı sonuçlar vermiştir. Türkiye' de özellikle 1990'lı y1llarda 15 aydan fazla iktidarda kalamayan koalisyon hükümetlerinin varlığı popülist programların oluşmasına neden olmuştur. Birçok sektörde gereksiz ve kalifiye olmayan iş gücünün istihdam edilmesi sonucu yüksek büyüme oranları enflasyona tercih edilmiştir. Ancak 2006 sonrası fiyat istikrarının MB tarafından temel değişken olarak belirlenmesi enflasyon oranlarında belli bir seviyede tutulmasına yol açmışıır. Ayrıca Merkez bankası ile hükümet arasındaki etkileşim politik istikrarın belirlenmesine önemli bir rol oynamıştır. Çünkü para politikalarıyla ekonomik istikrar arasındaki dengenin sağlanmasında ikili diyaloglar etkinliği arttırmaktadır. Seçim dönemlerinde hükümet, gelir sağlama amacıyla hazine ve MB arasında bir koordinasyon oluşturabilmektedir. Ancak MB üzerinde oluşturulacak siyasi baskılar gerekli ve ihtiyaç odaklı politikaların belirlenememesine yol açmaktadır. Ekonomide etkinliğin tam olarak sağlanmasında etkin ve bağımsız politikaların oluşturulması önemli bir etken oluşturmaktadır.

Çin ekonomisinde ise sosyalist eğilimlerin olması ekonomik sistem içerisinde de aynı etkilerin oluşmasına yol açmıştır. Mao'nun ölümünden sonra, Deng Xiaoping tarafindan ekonomide merkezi planlama sistemi değişerek yerel birimlere ait bir yönetim sistemine geçilmesi ekonomide olumlu sonuçlar oluşturmuştur. Dış ticarette serbestleşme politikaları, dış dünya ile etkileşim ve Çin'in Dünya Ticaret Örgütüne üye olmasılyla birlikte ekonomide büyük ölçüde iyileşmeler yaşanmıştır. Reform politikaları, yoksulluğun azaltılması için uygulanan politikalarla istihdamda artış sağlanmıştır. Düşük iş̧i maliyetleri nedeniyle doğrudan yatırımları ülkesinde toplayan Çin, iç pazarda önemli bir yer edinmiştir. Son dönemlerde yüksek büyüme performansı sağlayan ülkede üretim oranı yüksek seviyelerde seyir etmektedir.

Partizan modelde, partilerin esas amaçlarının kendi seçmen gruplarının yararına sonuçlar yaratacak politikalar izlemek olduğu öngörülmektedir. Politik partiler siyasi görüşlerinin sol veya sağında yer almalarına bağlı olarak, istihdam artışı ve enflasyon problemlerine farklı oranlarda ağırlıklar vermektedir. Hükümetler ülkelerindeki seçmen gruplarının tercih ettiği 
Şen ,A. ve C. Pehlivan, (2019), "Partizan Modelin Çin ve Türkiye Ekonomilerine Etkisinin İncelenmesi: Ampirik Bir Analiz”, Politik Ekonomik Kuram, Cilt 3(2)

politikaları belirleyerek ona uygun bir strateji izlemektedirler. İzlenen politikalar seçim öncesi ve sonrasında değil, iktidarın sağ ve sol görüşlü partiler arasında bulunmasına göre ekonomide politik devresel dalgalanmaların ortaya çıkmasına yol açmaktadır.

\section{KAYNAKÇA}

Akalın, G. ve Erkişi, K. (2007). Türkiye'de Seçim Ekonomisi Uygulamalarının Geleneksel Oportünist Seçim Çevrimleri Açısından Değerlendirilmesi. ZKÜ Sosyal Bilimler Dergisi, 3 (5), ss. 89-116.

Alesina, A. (1987). Macroeconomic Policy in a Two-Party System as a Repeated Game. Quarterly Journal of Economics, 102(3), ss. 651-678.

Alesina A., Cohen G. ve Roubini N. (1991). Macroeconomic Policy and Elections in OECD Democracies. NBER Working and Paper, no: 3830.

Alesina, A., Perotti R. ve Tavares, J. (1998). The Political Economy of Fiscal Adjustments. The Brookings Instution Journal, 29, ss. 197-266.

Akçoraoğlu, A. ve Yurdakul, F. (2004). Siyasal Ekonomi Açısından Büyüme, Enflasyon ve Bütçe Açıkları: Türkiye Üzerine Bir Uygulama. Ankara Üniversitesi SBF Dergisi, 59 (1), ss. 1-25.

Berger, H. ve Woitek, U. (1997). Searching for Political Business Cycles in Germany. Public Choice, 91 (2), ss. 179-197.

Bircan, H. ve Karagöz, Y. (2003). Box-Jenkıns Modelleri ile Aylık Döviz Kuru Tahmini Üzerine Bir Uygulama. Kocaeli Üniversitesi Sosyal Bilimler Enstitüsü Dergisi (6) 2003 / 2 : ss. 49-62.

Bräuninger, T. (2005). A Partisan Model of Government Expenditure. Public Choice, Vol. 125, No. 3-4, ss. 409-429.

Borooah, V. K. (1988). Public Choice Theory and Macro economic Policy. Public Choice, ss. 72-73.

Cusack, T. R. (2001). Partisanship in the Setting and Coordination of Fiscal and Monetary Policies. European Journal of Political Science. Vol.40, Issue 1, ss. 93115.

Dash, B. B. ve Raja, V. A. (2013). Do Political Determinants Affect the Size and Composition of Public Expenditure? A study of the Indian States. International Review of Economics, Vol. 60, Issue 3, 2013, ss. 293-317.

Enders, W. (2004). Applied Econometrics Time Series, Newyork, John Wiley and Sons, 2004, ss. 229. 
Şen ,A. ve C. Pehlivan, (2019), "Partizan Modelin Çin ve Türkiye Ekonomilerine Etkisinin İncelenmesi: Ampirik Bir Analiz”, Politik Ekonomik Kuram, Cilt 3(2)

Ergün, M. (2000). Electoral Political Business Cycles In Turkey. Yayınlanmamış Yüksek Lisans Tezi, Bilkent Üniversitesi, Sosyal Bilimler Enstitüsü, Ankara.

Frey, B. S. ve Schneider, F. (1978). An Empirical Study of Politico-Economic Interaction in the United States. Review of Economics and Statistics, 60 (2), ss. 174-183.

Frey, B. S. (1984). Politico-Economic Models and Cycles. The Theory of Public Choice II in, Ed: James M. Buchanan and Robert D. Tollison, The University of Michigan Press, ss. 305322.

Garand, J. C. (1988). Explaining Government Growth in the U.S. States. The American Political Science Review, Vol. 82, No. 3, ss. 837-849.

Gujarati, D. N. ve Porter, D. C (2012). Temel Ekonometri. (Ü. Şenesen \& G. G. Şenesen, Trans. 5 ed.). İstanbul: Literatür Yayıncılık.

Hibbs, D. (1977). Political Parties and Macroeconomic Policy. American Political Science Review, 71(4), ss. 1467-87.

Mc. Callum, B.T. (1995). Two Fallacies Concerning Central Bank Independence, American Economic Review, 85(2), ss. 201.

Nordhaus, W. D.(1975). The Political Business Cycle. The Review of Economic Studies, 42(2), Ss. $169-190$.

Özmen, A. (1986). Box-Jenkins Yöntemi ve Banka Mevduat Tahmininde Uygulamalar Denemesi, Anadolu Üniversitesi, Eşkişehir: 1986.

Özkan, F. ve Tarı, R. (2010). Türkiye'de 1980 Sonrası Seçim Dönemlerinin Politik Konjonktürel Dalgalanmaları Teorisi Çerçevesinde Analizi. Erciyes Üniversitesi İktisadi ve İdari Bilimler Fakültesi Dergisi, 36, 224, ss. 223-238.

Özsoylu, A. F. (1992). İç Borçların Siyasi Boyutları. Ankara Üniversitesi S.B.F. Dergisi, 47(34), ss. 280.

Serban, M. (2002). "Budget Deficit and Inflation”, Academy of Economic Studies, Doctoral School of Finance and Banking, Bucharest.

Sevüktekin, M. ve Nargeleçekenler, M. (2010). Zaman Serileri Analizi, (1.bask1), Nobel Yayınlar1, Ankara.

Sezgin, Ş. (2005). Politika ve Ekonomi İlişkisi: Türkiye'de Politik Konjonktürel Dalgalanmalar ve Ekonomik Oy Verme. Yayınlanmamış Doktora Tezi, Anadolu Üniversitesi Sosyal Bilimler Enstitüsü, Eskişehir.

Telatar, F. (2000). Parlamenter Sistemlerde Politik Devresel Dalgalanmalar. Gazi Üniversitesi İ̇̈F Dergisi, 4, ss. 133-154. 
Şen ,A. ve C. Pehlivan, (2019), “Partizan Modelin Çin ve Türkiye Ekonomilerine Etkisinin İncelenmesi: Ampirik Bir Analiz”, Politik Ekonomik Kuram, Cilt 3(2)

Treisman, D. ve Gimpelson, V. (2001). Political Business Cycle and Russian Elections, or The Manipulations of Chudar. British Journal of Political Science, 31 (4), ss. 225-246.

Uygur, E. (2001). “Enflasyon, Para ve Mali Baskı:İktisat Politikasında Geri Kalmışlık”, İktisat İşletme ve Finans, Yı1: 16, Sayı: 189.

Yavuz, N.Ç. (2014). Finansal Ekonometri, (1.baskı), Der Yayınları, İstanbul.

Walter E. (2004). Applied Econometric Time Series, Inc: Iowa State University, John Wiley \& Sons.

William, N. (1975). The Political Business Cycle. Review of Economic Studies, Vol:42, ss. 169-190.

\section{EKLER}

Ek 1: Türkiye’nin Oto Korelasyon ve Kısmi Korelasyon Değerleri

\begin{tabular}{|c|c|c|c|c|c|c|}
\hline Autocorrelation & Partial Correlation & & $\mathrm{AC}$ & PAC & Q-Stat & Prob \\
\hline$. * \mid$ & $* *$ & 1 & -0.138 & -0.138 & 0.5769 & 0.448 \\
\hline $.1^{*}$. & \begin{tabular}{l|l|}
. &. \\
\end{tabular} & 2 & 0.076 & 0.058 & 0.7567 & 0.685 \\
\hline .1 & \begin{tabular}{l|l}
. &.
\end{tabular} & 3 & -0.046 & -0.028 & 0.8246 & 0.844 \\
\hline$. * * \mid$. &.$* *$. & 4 & -0.299 & -0.320 & 3.8581 & 0.426 \\
\hline . $\left.\right|^{*}$. & \begin{tabular}{l|l}
. &. \\
\end{tabular} & 5 & 0.135 & 0.066 & 4.5035 & 0.479 \\
\hline.$^{* *}$. &.$*$. & 6 & -0.131 & -0.073 & 5.1461 & 0.525 \\
\hline . $\left.\right|^{*}$. &.$\left.\right|^{*}$. & 7 & 0.210 & 0.156 & 6.8683 & 0.443 \\
\hline.$\left.\right|^{*}$ &.$\left.\right|^{*}$. & 8 & 0.096 & 0.080 & 7.2482 & 0.510 \\
\hline$.^{*} \mid$. & \begin{tabular}{l|l}
. &. \\
\end{tabular} & 9 & -0.096 & -0.062 & 7.6468 & 0.570 \\
\hline .1. & $.^{*} \mid$. & 10 & -0.019 & -0.109 & 7.6633 & 0.662 \\
\hline *** & $* \mid$. & 11 & -0.268 & -0.174 & 11.170 & 0.429 \\
\hline .1. & $.^{*} \mid$. & 12 & -0.033 & -0.088 & 11.226 & 0.510 \\
\hline
\end{tabular}

\section{Ek 2: Çin'in Oto Korelasyon ve Kısmi Korelasyon Değerleri}

\begin{tabular}{|c|c|c|c|c|c|c|}
\hline Autocorrelation & Partial Correlation & & $\mathrm{AC}$ & PAC & Q-Stat & Prob \\
\hline.$* 1$. & $*$ & 1 & -0.131 & -0.131 & 0.5021 & 0.479 \\
\hline \begin{tabular}{l|l}
. &. \\
\end{tabular} & $*$. & 2 & -0.275 & -0.298 & 2.8012 & 0.246 \\
\hline.$\left.\right|^{*}$. & $\begin{array}{l}.1 . \\
.\end{array}$ & 3 & 0.119 & 0.037 & 3.2485 & 0.355 \\
\hline ***. & $* * *$ & 4 & -0.020 & -0.086 & 3.2621 & 0.515 \\
\hline$*$ & $* *$ & 5 & -0.177 & -0.166 & 4.3450 & 0.501 \\
\hline \begin{tabular}{l|l}
. &. \\
\end{tabular} & \begin{tabular}{l|l}
. &. \\
\end{tabular} & 6 & 0.044 & -0.048 & 4.4153 & 0.621 \\
\hline.$\left.\right|^{*}$ & .1. & 7 & 0.079 & -0.011 & 4.6526 & 0.702 \\
\hline$. * \mid$. & \begin{tabular}{l|l}
$* *$ &. \\
\end{tabular} & 8 & -0.187 & -0.187 & 6.0673 & 0.640 \\
\hline .*1. & $*$. & 9 & -0.082 & -0.170 & 6.3565 & 0.704 \\
\hline .1. & $.^{*} \mid$. & 10 & 0.054 & -0.151 & 6.4870 & 0.773 \\
\hline \begin{tabular}{l|l}
. &. \\
\end{tabular} & \begin{tabular}{l|l}
$*$ &. \\
\end{tabular} & 11 & -0.015 & -0.123 & 6.4980 & 0.838 \\
\hline \begin{tabular}{l|l}
. &. \\
\end{tabular} &. & 12 & 0.067 & -0.006 & 6.7333 & 0.875 \\
\hline
\end{tabular}

Not: Zaman serisinde yer alan gecikmeler modele uygun MA mertebesini belirlemek veya herhangi bir azalış olması durumunda AR etkisini ifade etmekte kullanılmaktadır. Ayrıca oto korelasyon katsayılarının 
Şen ,A. ve C. Pehlivan, (2019), "Partizan Modelin Çin ve Türkiye Ekonomilerine Etkisinin İncelenmesi: Ampirik Bir Analiz”, Politik Ekonomik Kuram, Cilt 3(2)

tamamına yakınının güven bandının içinde olması serinin durağan olduğunu göstermektedir. Dördüncü gecikmeye ait ilişkinin önemli olması nedeniyle gecikme değerleri AR ve MA için dört gecikme olarak kullanılmıştır.

\section{Ek 3: Türkiye'nin AR MA $(4,4)$ Modeline İlişkin Tahmin Sonuçları}

$\begin{array}{llll}\text { Parametre } & \begin{array}{l}\text { Parametre } \\ \text { Tahminleri }\end{array} & \text { t-Değeri } & \text { Olasılık } \\ \text { AR(1) } & -0.956 & -17.45 & 0.000 \\ \text { AR(2) } & 0.214 & 2.459 & 0.001 \\ \text { AR(3) } & 0.302 & 4.478 & 0.004 \\ \operatorname{AR}(4) & -0.195 & -3.69 & 0.000 \\ \operatorname{MA}(1) & -1.076 & -15.789 & 0.001 \\ \operatorname{MA}(2) & 0.269 & 31.891 & 0.000 \\ \operatorname{MA}(3) & 0.714 & 45.742 & 0.000 \\ \operatorname{MA}(4) & 0.742 & 43.452 & 0.000\end{array}$

Not: Olasılık değerleri 0.01anlam seviyesinde istatistiksel olarak anlamlı olduğunu göstermektedir. Modeldeki tüm parametreler için elde edilen olasılık değerleri anlamlıdır.

\begin{tabular}{clll} 
Ek 4: Çin'in AR MA (4,4) & \multicolumn{3}{c}{ Modeline İlişkin Tahmin Sonuçları } \\
Parametre & Parametre & t Değeri & Olasılık \\
& Tahminleri & & \\
AR(1) & 0.782 & 33.425 & 0.000 \\
AR(2) & 0.412 & 2.453 & 0.001 \\
AR(3) & -1.145 & -14.478 & 0.003 \\
AR(4) & 0.932 & 5.478 & 0.000 \\
MA(1) & -0.431 & -11.459 & 0.004 \\
MA(2) & 0.499 & 2.412 & 0.000 \\
MA(3) & 0.441 & 2.113 & 0.000 \\
MA(4) & 0.710 & 41.239 & 0.001
\end{tabular}

Not: Olasılık değerleri 0.01anlam seviyesinde istatistiksel olarak anlamlı olduğunu göstermektedir. 